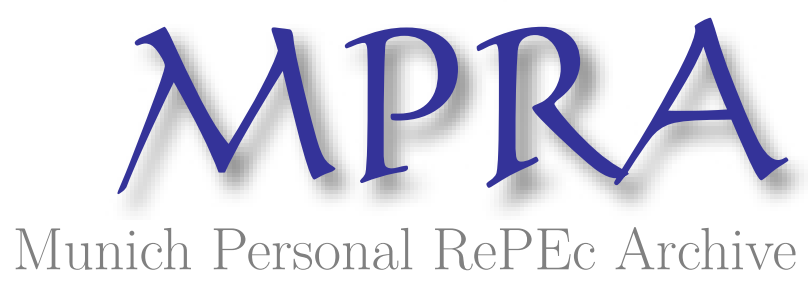

\title{
Theories of financial inclusion
}

Ozili, Peterson K

2020

Online at https://mpra.ub.uni-muenchen.de/101810/

MPRA Paper No. 101810, posted 19 Jul 2020 01:56 UTC 


\title{
Theories of financial inclusion
}

\author{
Peterson K. Ozili Ph.D.
}

\begin{abstract}
This article presents several theories of financial inclusion. Financial inclusion is the ease of access to, and the availability of, basic financial services to all members of the population. Financial inclusion means that individuals and businesses have access to useful and affordable financial products and services that meet their needs in a responsible and sustainable way. Financial inclusion practices vary from country to country, and there is need to identify the underlying principles or propositions that can explain the observed variation in financial inclusion practices. These set of principles or propositions are called theories. Financial inclusion theories are explanations for observed financial inclusion practices. The study shows that the ideas and perspectives on financial inclusion can be grouped into theories to facilitate meaningful discussions in the literature. The theories are intended to be useful to researchers, academics and practitioners. The resulting contributions to theory development are useful to the problem-solving process in the global financial inclusion agenda.
\end{abstract}

Keywords: financial inclusion, theory, financial access, access to finance, dissatisfaction theory, vulnerable group, systems theory, community echelon, public service, special agent, financial literacy, collaborative intervention, intervention fund, households.

JEL Classification: G00, G21, O16

This version: January, 2020. 


\section{Introduction}

I seize this occasion to break the silence among those of us that have observed the recent trend in financial inclusion practice particularly the cross country differences in financial inclusion practice, and are worried that the modern trend in financial inclusion practice lacks an underlying theory or a set of guiding principles that can help to improve our understanding of financial inclusion as a pro-development initiative in the economics and finance discipline. As new academics emerge and are eager to understand financial inclusion in a fast changing world where sophisticated financial innovations have increased rapidly in the formal financial sector, it is needful to remind ourselves that the financial inclusion literature may become porous and disconnected if there are no set of coherent theories of financial inclusion to prescribe some general principles that explain financial inclusion practice.

Today, there are many studies on financial inclusion and I am immensely thrilled by the interesting findings of empirical research in financial inclusion especially policy research and academic research (DemirgucKunt et al, 2017). But the notable lack of synergy between the policy and academic literatures (Prabhakar, 2019), and the neglect of the role of theory in financial inclusion debates and research is worrisome. My first response to this realization was to ignore it, hoping that some good might come of it. But it is difficult to ignore the lack of theory, because in the financial inclusion literature, ideas have become texts, and opinions have become stylized facts in the literature. In fact, proponents of financial inclusion do not challenge the current financial innovation products and systems used in achieving financial inclusion because they do not want be seen as being anti-innovation or anti-development.

Currently, there are no observed or elaborate theories of financial inclusion in the policy or academic literature. In fact, I have heard colleagues in top policy-making institutions make statements like "we don't need a theory of financial inclusion". Some feel that "building a theory of financial inclusion is a waste of time". Others think that "theorizing financial inclusion would lead to lack of relevance to practitioners and policymakers". In sum, the general conception is that it is better to focus on the accumulation of evidence on financial inclusion than concentrating on building theories of financial inclusion, and even when some financial inclusion theories emerge, there will be contentions about what is a theory and what is not a theory, whether we should have a single unifying theory of financial inclusion or multiple theories of financial inclusion, whether we should rely on old or new theories, and there will be arguments about the degree of abstraction embedded in old and new theories. Despite the disagreements on the value of theory in the financial inclusion debate, we can at least agree that we need a framework or a set of principles to help us understand what financial inclusion is, how it is achieved and who benefits from financial inclusion. These principles are called theories.

In this paper, I present several theories of financial inclusion that can be useful to academics and practitioners. These theories are divided into theories of financial inclusion beneficiaries, theories of financial inclusion funding, and theories of financial inclusion delivery. ${ }^{1}$ Of course, no theory is perfect and I have been careful to reduce the degree of abstraction in the theories in order to increase the relevance of these theories to both academics, practitioners and policymakers. Each of the theories discussed in this

\footnotetext{
${ }^{1}$ These theories may be also categorized into demand-side theories and supply-side theories from an economic perspective.
} 
paper can be expanded into large volumes of texts to take into account a wide range of philosophical dimensions and critical perspectives of the theory but, due to space constraints, I have presented an abridged and concise version of each of the theories and I would gladly welcome any requests to expand each of the theories to be published as a single theoretical paper. I hope the reader would find the theories useful for intellectual discourse for future research in financial inclusion. While the aim of the paper is not to critique studies that lack theoretical perspectives, I will make reference to such studies for illustration purposes.

This paper contributes to the financial inclusion literature. By articulating a general theory or theories of financial inclusion, I present a new and comprehensive statement of what the financial inclusion enterprise should be about. I argue that the financial inclusion literature - whether academic or policy can use theories to provide believable explanations for financial inclusion objectives and outcomes. Policy makers can also use these theories to justify the various strategies they adopt in achieving financial inclusion.

The remainder of the paper is organized as follows. Section 2 presents some foundations for financial inclusion. Section 3 discuss the theories that explain who benefits from financial inclusion. Section 4 discuss the theories that explain the agent responsible to deliver financial inclusion to the beneficiaries. Section 5 discuss the theories on how financial inclusion is funded. Section 6 concludes.

\section{Some foundations}

Financial inclusion is the provision of access to financial services to all members of population particularly the poor and the other excluded members of the population (Ozili, 2018). Financial inclusion can also be defined as the delivery of banking services at an afford able cost to the vast sections of the disadvantaged and low-income groups (Dev, 2006). Financial inclusion is also defined as the use of, and access to, formal financial services (Sahay et al, 2015). These definitions have one thing in common which is that they emphasize that each member of the population should have access to available financial services.

Financial inclusion has been a major policy objective for the government of many developing and emerging countries, and there is great promise that financial inclusion will bring the excluded population into the formal financial sector so that they can have access to formal financial products and services (Allen et al, 2016). Many governments are making tremendous efforts to achieve high levels of financial inclusion for the benefit of their citizens. There are many success stories on financial inclusion around the World particularly in India (Nimbrayan et al, 2018), Rwanda (Lichtenstein, 2018; Otioma et al, 2019), Kenya (Ndung'u, 2018; Hove and Dubus, 2019) and Peru (Cámara and Tuesta 2015). In India, the PMJDY scheme improved the level of financial inclusion for many of its citizens and became a big success in the early years. ${ }^{2}$ The later years of the PMJDY scheme witnessed some supply-side challenges such as low supply incentives and low subsidy to providers of financial services. ${ }^{3}$ In Rwanda, community savings and credit

\footnotetext{
${ }^{2}$ https://www.pmjdy.gov.in/files/stories/Central-Bank-of-India.pdf

${ }^{3}$ https://www.cgap.org/blog/pmjdy-improved-financial-inclusion-roadblocks-remain
} 
cooperatives have been a financial inclusion success story. In just three years, these cooperatives, known as Umurenge SACCOs, have attracted over 1.6 million customers and $90 \%$ of Rwandans now live within a $5 \mathrm{~km}$ radius of an Umurenge SACCO. ${ }^{4}$ In Kenya, the M-Pesa has been the primary instrument to achieve greater financial inclusion for the Kenyan people. The introduction of M-Pesa in 2007 profoundly transformed Kenya's financial system. Through the M-Pesa, the level of financial inclusion rose from $26.4 \%$ in 2006 to $40.5 \%$ in 2009 and the level of financial exclusion declined from $39.3 \%$ to $33 \% .{ }^{5}$ In Peru, an interoperable mobile money platform called 'Modelo Peru' was launched that focuses on bringing mobile financial services to those who need it, with the aim of promoting financial inclusion. There is also the 'Bim' service in Peru that enables any Peruvian with a mobile phone to open a bank account and make payments and this can be done without ever having to visit a bank. ${ }^{6}$ There is no doubt that the financial inclusion programmes and policies adopted in some countries have been successful. Yet, the two major concerns that often arise is the concern that financial inclusion may spread the risks of the financial system to the poor and vulnerable customers in society and increase the number of high-end (or high-income) consumers benefiting from financial institutions. The second concern is whether financial inclusion should be targetted to those who have never been included in the formal financial sector or to those who have been relatively distant to using financial products more and more frequently.

The policy literature contains many idealistic interpretations on how to achieve financial inclusion while the academic literature is mostly focused on the relationship between financial inclusion and poverty levels and income inequality as well as the effect of financial inclusion on the economy (Sarma and Pais, 2011; Morgan and Pontines, 2014; Mehrotra and Yetman, 2015; Demirgüç-Kunt and Klapper, 2013a; Cull et al, 2013). These two literatures are quite interesting even though there is no synergy between the academic and policy literatures. But, theories are powerful because they can help to bring the two literatures together. Theories can explain why different ideas exist on what financial inclusion objectives should be and how to achieve financial inclusion. Theories can explain the current observations in financial inclusion practice and can also explain abnormal deviations that exist in practice so that a coherent and comprehensive system of principles for financial inclusion can be developed. Therefore, a good financial inclusion theory or set of theories is one that provide a system of ideas to explain financial inclusion objectives, processes or outcomes.

Some observed financial inclusion practices include: the opening of bank accounts with minimal documentation requirements, using ultimatums to compel citizens to obtain a bank verification number, granting free debit cards, granting free insurance policies, using mobile technology to access finance, adopting a direct government to person (G2P) payment system, enrolling for mortgage without having to make compulsory equity down payment, the large-scale use of bank correspondents, among others. To understand why certain financial inclusion objective yield certain outcomes such as those described

\footnotetext{
${ }^{4}$ https://www.afi-global.org/sites/default/files/publications/afi case study rwanda finalweb.pdf

${ }^{5}$ https://www.bsg.ox.ac.uk/sites/default/files/2018-06/2017-07-M-Pesa-Practitioners-Insight.pdf

${ }^{6}$ https://www.mastercardcenter.org/insights/modelo-peru-collaboration-creates-interoperability
} 
above, we also need to understand the behavior of the agents involved in the financial inclusion process and a theory or principles of financial inclusion can help explain this as well. A financial inclusion theory is therefore an explanation for observed financial inclusion practices.

Why do we need a theory or set of theories of financial inclusion? We need a theory of financial inclusion to achieve a high level of synthesis between financial inclusion objectives and financial inclusion outcomes. A financial inclusion theory or set of theories would provide a system of ideas that can explain financial inclusion objectives, processes and outcomes. Secondly, financial inclusion theories can consolidate the recent idealistic debates in the policy literature on financial inclusion. Thirdly, financial inclusion theories can provide a set of principles on which the practice of financial inclusion is based, and would make it possible to detect abnormal patterns in financial inclusion practice which would elicit further research to improve our understanding on why unexpected deviations exist in practice. Generally, in problem-driven social science research, researchers often use one or multiple theories to assess a problem and use one or multiple theories to solve or prevent a problem. This suggest that the theories for describing a financial inclusion problem may differ from the theories for its solution. Similarly, the theories for identifying the beneficiaries of financial inclusion may differ from the theories for the delivery and funding of financial inclusion activities.

\section{Theories of financial inclusion beneficiary}

Conflicting ideas or perspectives exist on who benefits from financial inclusion outcomes. Some studies argue that poor people are the ultimate beneficiaries of financial inclusion (Bhandari, 2018), others think that women are the beneficiaries of financial inclusion outcomes (Ghosh and Vinod, 2017; Demirguc-Kunt et al, 2013b; Swamy, 2014) while some think that the economy and the financial system are beneficiaries of financial inclusion (Mehrotra and Yetman, 2015; Kim et al, 2018; Swamy, 2014: Ozili, 2018). Apart from women and poor people, there are other potential beneficiaries of financial inclusion that have been ignored to a large extent in the literature such as young people, elderly people, institutionalized and ill people, disabled people, and individuals who have been previously expelled from the financial sector for various reasons such as committing criminal offenses. ${ }^{7}$ Below are four theories that explain who benefits from financial inclusion.

\subsection{Public good theory of financial inclusion}

The public good theory of financial inclusion argues that the (i) delivery of formal financial services to the entire population and (ii) ensuring that there is unrestricted access to finance for everyone, should be treated as a public good for the benefit of all members of the population. As a public good, individuals cannot be excluded from using formal financial services and individuals cannot be excluded from gaining access to financial services. All individuals will enjoy basic financial services without paying for it. Access to financial services to one individual does not reduce its availability to others which means that all

\footnotetext{
7 The World bank's perspective on the beneficiaries of financial inclusion does not include these potential beneficiaries. In fact, the World Bank (2018) conclude that poor households and women as the ultimate beneficiaries of financial inclusion, which is quite restrictive.
} 
members of the population can be brought into the formal financial sector and everyone will be betteroff. Under this theory, all members of the population are beneficiaries of financial inclusion and nobody is left out. Under the public good theory, any individual or small business that open a formal bank account can be offered free debit cards, they can also use the ATM machines to perform transactions without being charged a transaction fee. Also, the suppliers of financial services such as financial institutions will have to bear the cost of offering financial services as a sunk-cost of doing banking business. Also, the government can grant subsidy to financial institutions to help them cope with any resulting cost problems that may arise from offering free financial services. A government can even offer a lump-sum cash deposit into the bank account of all citizens and make owning a formal account the only requirement for individuals to access the free deposits. This means that individuals who cannot pay their debts and who cannot meet their basic needs at the micro level will stand a chance to be economically empowered when financial inclusion is viewed as public good.

This theory has two merits. Firstly, the public good theory suggest that everyone will benefit from financial inclusion regardless of status or income level. This means that both the rich and the poor, the financiallyincluded citizens and the financially-excluded citizens will enjoy the benefits of financial inclusion. Secondly, as a public good, achieving financial inclusion would require public funding rather than private funding because investors would require a premium on private funding which is costly when private funds are used to achieve financial inclusion objectives. Thirdly, as a public good, it gives the government an opportunity to take responsibility for promoting financial inclusion. Finally, the public good theory of financial inclusion does not recognize private-sector agents as promoters of financial inclusion.

The public good theory has four demerits. Firstly, treating financial inclusion as a public good does not address the real cause of financial exclusion in the first place. Secondly, treating financial inclusion as a public good which requires public funding can divert public funds away from other important public projects in order to fund financial inclusion projects. Thirdly, the public good theory assumes that financial inclusion as a 'public good' is free-of-charge and has no cost to the end-users of financial services. When financial inclusion is treated as a public good, the level of financial inclusion may not be sustainable in the long-term even when supported with public funding if it comes at no cost to end-users. Four, the public good theory of financial inclusion may have little relevance for developing and emerging economies because financial institutions and banks operating in developing countries and emerging economies are mostly funded on private investments rather than public investments, for this reason, it can be difficult to make financial inclusion a public $\operatorname{good}^{8}$ in such countries.

\subsection{Dissatisfaction theory of financial inclusion}

The dissatisfaction theory of financial inclusion argues that financial inclusion activities and programs in a country should first be targeted to all individuals who were previously on-boarded into the formal financial sector but left the formal financial sector because they were dissatisfied with the rules of

\footnotetext{
${ }^{8}$ Actually, in Africa the nature of governments and governance problems have forced countries to privatized most of the public banks. In the era of public banks, the inability to break-even, lack of sustainability and low profitability, unnecessary bureaucracy and corruption were the problems faced by public sector banks which became a major constrain in the provision of financial services as a public good by public sector banks.
} 
engagement in the formal financial sector, or had other unfavorable personal experiences from dealing with firms and agents in the formal financial sector. ${ }^{9}$ This theory suggests that it is easier to bring back people who left the formal financial sector because they were dissatisfied if the areas of dissatisfaction in the formal financial sectors have been completely resolved. It is easier to bring back this group of individuals into the formal financial sector through persuasion than to bring in those who have never been in the formal financial sector. The implication of this theory is that the members of the population that left the formal financial sector should be the first target of financial inclusion before extending financial inclusion policies and programs to other members of the population who have never been on-boarded into the formal financial sector. Previously on-boarded individuals may become dissatisfied for several reasons such as when they are victims of financial fraud, debit/credit card fraud, financial theft, long waiting hours before depositors are able to withdraw funds, taking too long before payments are cleared, high transaction costs, excessive bank charges, etc.

The dissatisfaction theory of financial inclusion has some merits. Firstly, this theory is a deliberate attempt to deal with the 'voluntary financial exclusion' problem which other theories do not address. It reduces the level of voluntary financial exclusion by using persuasion to bring back those that left the formal financial sector due to dissatisfaction. Secondly, under this theory, it is easy to identify the financiallyexcluded members of the population. The previously on-boarded members of the population can be easily identified because their personal data are stored with financial institutions, and they can be reached to be persuaded to return to the formal financial sector. It is easier to achieve financial inclusion by reaching out to previously on-boarded individuals compared to achieving financial inclusion for members of the population that have never been to the formal financial sector. Thirdly, achieving financial inclusion does not require the use of public funding since it relies strongly on interpersonal persuasive skills and abilities.

The dissatisfaction theory has some demerits. Firstly, the theory does not prioritize financial inclusion for everybody in the population. It excludes people who have never been to the formal financial sector. Secondly, it ignores poor people in remote areas where formal financial institutions do not exist. Thirdly, the dissatisfaction theory implicitly assumes that financial exclusion is caused by customers' dissatisfaction with the rules of engagement in the formal financial sector. This may not be the case under certain circumstances because individuals can voluntarily withdraw from the formal financial sector for other reasons such as religious and personal reasons (Ozili, 2018). Finally, individuals who are dissatisfied with the formal financial sector may have no choice but to remain in the formal financial sector if the societal culture relies too much on the formal financial sector.

\subsection{Vulnerable group theory of financial inclusion}

The vulnerable group theory of financial inclusion argues that financial inclusion activities or programs in a country should be targeted to the vulnerable members of society such as poor people, young people, women, and elderly people who suffer the most from economic hardship and crises. Vulnerable people are often the most affected by financial crises and economic recession, therefore, it makes sense to bring

\footnotetext{
${ }^{9}$ Such unfavorable experiences may include debit/credit card frauds, long waiting periods before depositors are able to withdraw funds, taking too long before payments are cleared, high transaction costs, excessive bank charges, etc.
} 
these vulnerable people into the formal financial sector. One way to achieve this is through governmentto-person (G2P) social cash transfers into the formal account of vulnerable people. Making G2P social cash transfer payments into the formal account of poor people, young people, women, and elderly people will encourage other poor people, young people, women, and elderly people to join the formal financial sector to own a formal account to take advantage of the social cash transfer benefits, thereby, increasing the rate of financial inclusion for vulnerable groups. Also, when social cash transfer is working, and other tools for achieving financial inclusion are provided to vulnerable people in society, it can make vulnerable people feel that they are being compensated for the current income inequality that affect them, which gives them an opportunity to catch up with the other segments of society. The implication of theory is that it identifies some members of the population to be vulnerable, and suggest that financial inclusion efforts should be the targeted to the vulnerable people in society.

The vulnerable group theory of financial inclusion has some merits. Firstly, the theory makes an attempt to reduce the financial exclusion problem by targeting vulnerable groups for financial inclusion and to bring them into the formal financial sector. Secondly, under this theory, it is easy to identify the financiallyexcluded members of the population. The vulnerable members of the population can be identified by their degree of vulnerability, income level, gender, age, and other demographic characteristics. Thirdly, it may be cost-effective to target only the vulnerable members of the population for financial inclusion compared to achieving financial inclusion for the entire population.

The vulnerable group theory has some demerits. Firstly, the theory does not prioritize financial inclusion for everybody in the population. Secondly, it ignores non-vulnerable people outside the formal financial sector. Non-vulnerable people also need access to the formal financial sector too! Thirdly, it assumes that women are a vulnerable group, which implies that men are not a vulnerable group. This idea is critical because in modern societies women and men compete for equal opportunities, therefore labelling women as vulnerable groups to the exclusion of men could have unintended consequences for financial and social inclusion. It could lead to societal resentment among the men towards women. Finally, achieving financial inclusion by targeting vulnerable people may lead to increasing social inequality when social policies are designed to favour vulnerable people over others, and it may also lead to income inequality if vulnerable people receive better access to financial services than others.

\subsection{Systems theory of financial inclusion}

The systems theory of financial inclusion states that financial inclusion outcomes are achieved through the existing sub-systems (whether economic, social or financial systems) which financial inclusion rely on, and as a result, greater financial inclusion will have positive benefits for the systems it relies on. A significant change in a sub-system (one part of the system) can significantly affect the expected financial inclusion outcomes, for instance, imposing regulations on economic agents and suppliers of financial services - who are a part of the economic and financial system - can align their interests with that of the users of basic financial services which can compel economic agents and suppliers of financial services to offer affordable and quality financial services to users within defined rules that protect users of financial services from exploitation and price discrimination. 
On the other hand, a significant change at the full system level - such as replacing the existing national financial inclusion plan with a completely new plan - does not necessarily lead to a change in the existing sub-systems because a change in the sub-system must be done at the sub-system level. The theory suggests that financial inclusion will improve the workings of the sub-systems it rely on, while the efficiency and effectiveness of the sub-systems will determine the success or failure of a financial inclusion agenda. But in the end, the existing sub-systems (economic, financial and social) in a country are the ultimate beneficiaries of financial inclusion, under the systems theory perspective.

The systems theory of financial inclusion has some merits. Firstly, the systems theory recognizes the role of existing economic, financial and social systems or structures in a country in promoting financial inclusion. Secondly, it provides a macro perspective on financial inclusion compared to other theories with a micro-perspective. Thirdly, systems theory of financial inclusion considers how financial inclusion outcomes are affected by the interrelationship among the sub-systems that financial inclusion relies on.

The systems theory has some demerits. Firstly, the existing systems are a reflection of the environment. In some environments, the existing systems may not function properly, and as a result, the expected financial inclusion outcomes may not be achieved. Secondly, systems theory of financial inclusion does not recognize the influence of factors outside the system that could affect financial inclusion outcomes, rather it focuses on the effect of the system and its sub-systems on financial inclusion outcomes. Thirdly, systems theory of financial inclusion assumes that there is a direct relationship between financial inclusion outcomes and the systems it relies on.

\section{Theories of financial inclusion delivery}

There are several ideas on who should deliver financial services to the people. Some think the government should deliver financial inclusion to the people (Aggarwal and Klapper, 2013; Staschen and Nelson, 2013; Chibba, 2009). Others argue that private companies such as banks and fintech businesses can deliver financial inclusion more efficiently (Gabor and Brooks, 2017; Ozili, 2018). There are also ideas suggesting that financial inclusion can be delivered through cooperation by the public and private sectors (Arun and Kamath, 2015; Pearce, 2011). These expectations regarding financial inclusion delivery need an underlying thought-process to establish why these agents are necessary in the first place to deliver financial inclusion; hence, there is need for theories of financial inclusion delivery. Some theories or perspectives on financial inclusion delivery are provided below:

\subsection{Community echelon theory of financial inclusion}

Community echelon theory states that financial inclusion should be delivered to the financially-excluded population through their communal leaders. The community echelon theory argues that community leaders are influential in their communities and can use their influence to encourage or persuade community members to participate in the formal financial sector. Community plays an important role in shaping the values of its leaders and members. Community members trust their leaders and believe their leaders would make decisions that are beneficial to them while community leaders ensure that the decisions they make reflect the values and ethos held by members of the community. Community leaders 
can be instrumental in bringing their members into the formal financial sector because the strong cultural ties between community leaders and members makes it possible for community leaders to encourage their members to participate in the formal financial sector. If community leaders change their beliefs and preferences towards participating in the formal financial sector, community leaders can encourage their members to participate in the formal financial sector. Since communal outcomes are mostly predicted by the preferences, beliefs and other idiosyncrasies of community leaders, it makes sense to deliver financial inclusion to members of the community through their communal leaders.

The most important merit of the community echelon theory of financial inclusion is that communal leaders can influence community members into making changes that improve their welfare. The community echelon theory has some demerits. One, the influence of communal leaders can rebound if communal leaders are self-serving and corrupt. Secondly, communal leaders can make abrupt decisions that are not in the best interest of the people if the leaders are pressured by corporate promoters of financial innovation. Since communal leaders are believable, decisions that are not in the best interest of the community members can be reached, and can have negative implications on the welfare of community members. Thirdly, community members already participating in the formal financial sector may have worries and anxiety about the formal financial sector which they may not articulate to their community leaders. The higher the anxiety, the less likely they will remain in the formal financial sector for a long time. Also, serious agency problems may arise in the form of nepotism, fraud and corruption. Finally, since there are different leadership styles, it is difficult to determine which leadership style works best to influence community members to change their beliefs towards participating in the formal financial sector.

\subsection{Public service theory of financial inclusion}

Public service theory of financial inclusion states that financial inclusion is a public responsibility which the government owe its citizens, and the citizens expect the government to promote financial inclusion for its citizens. This theory argues that financial inclusion should be delivered to all citizens including the financially-excluded population by the government through public institutions. Under this theory, only the government is instrumental in achieving financial inclusion that brings all members of the population into the formal financial sector so that each member of the population can have access to formal financial products and services.

The public service theory has some merits. One, the theory suggest that financial inclusion can be achieved when the government chooses to be responsible for financial inclusion. Secondly, the government has control over the financial system, economic and social structures in the country which the government can use to achieve its financial inclusion objectives, for example, the government can establish public banks in the most remote areas of the country to reach the excluded members of the population. Thirdly, there is increased public confidence when the government assumes full responsibility for financial inclusion through public institutions. Members of the population are confident that all financial inclusion activities and programs will work for the greater good of everyone when the government takes full responsibility for financial inclusion. 
Some demerits of the public service theory include the following. One, it does not consider private-sector participation in promoting financial inclusion. Secondly, it assumes financial inclusion will be funded with taxpayers' money. Tax revenue may be insufficient to fund large financial inclusion programs. Thirdly, under the public service theory perspective where the State is responsible for financial inclusion through its public institutions, one disadvantage is that the State can use political power as a means of control over society. The state can provide basic financial services to obedient citizens and during good times, and can stop providing basic financial services when the citizens collectively choose to revolt against the State.

\subsection{Special agent theory of financial inclusion}

The special agent theory of financial inclusion argues that the delivery of financial inclusion to the excluded population can be hampered by complex issues and technicalities relating to the nature of the community, its people or the geography; therefore, there is need for specialized agents to deliver financial inclusion to members of the excluded communities. Under this theory, the special agent is expected to be: (i) a highly skilled and specialized agent, (ii) understand the peculiarities of the excluded population, (iii) understand the existing informal financial system in the communities where the excluded members of the population reside, (iv) identify areas for improvement through innovation, and (v) devise a means of integrating the local financial system into the formal financial sector.

The special agent is considered to be competent, highly skilled and have superior ability to bring the excluded population into the formal financial sector so that they can have access to formal financial products and services. Under this theory, there is a special agent relationship with the principal. The principal is often the national government, foreign government or foreign organizations while the special agent is often a local bank, non-bank institution or other special institutions created for the sole purpose of achieving financial inclusion. Financial institutions and technological companies such as financial technology (Fintech) companies can also play the role of special agent.

The special agent theory of financial inclusion has some merits. Firstly, it employs the services of specialized agents to promote financial inclusion in the country. Employing the services of specialized agents to promote financial inclusion in the country will allow the government to focus on other important and pressing national issues. Secondly, there is high degree of confidence in the ability of special agents to deliver financial inclusion to the excluded population. The special agents comprise of skilled individuals and experts affiliated with, or in collaboration, with other specialized institutions to harness collaborative inputs to reach the common goal of greater financial inclusion. Thirdly, there is no ambiguity about the financial inclusion targets to be achieved, and the compensation to the special agent is pre-agreed. The special agent knows what the target is, they know the expectations and are committed to meet the target, and they know the compensation to be received for their work, thus there is no ambiguity. Finally, the special agent relationship is not affected by the fundamental principal-agent problems in agency theory because the special agent deals with people, not money! The principal-agent problem in agency theory occurs when the agent, who is the manager of a firm, is driven by self-interest to appropriate excess financial resources (money) to oneself at the expense of shareholders (see Jensen and Meckling, 1976 for agency theory). 
The special agent theory of financial inclusion has some demerits. Firstly, if the principal is the government, the government may choose its own agency as the special agent, making the government both the principal and the agent. This would defeat the purpose of special agency for promoting financial inclusion. The government should not be the principal and the special agent at the same time because government agencies are inherently plagued with inefficiencies in the public sector. Secondly, a private special agent will abandon the financial inclusion project when there is a breach in contractual terms or a breach in conditions for service which may arise from insufficient compensation to the special agent by the government or the failure of the government to provide agreed funds to finance the financial inclusion projects as agreed in the contract.

\subsection{Collaborative intervention theory of financial inclusion}

Collaborative intervention theory states that financial inclusion should be achieved through collaborative intervention from multiple stakeholders. The theory suggests that joint effort from multiple stakeholders is needed to bring the excluded population into the formal financial services. This theory has some merits. One, it encourages a multi-stakeholder approach to achieve financial inclusion. Secondly, the collaborating stakeholders have a sense of satisfaction for being a significant contributor to a public project. The collaborative intervention theory has some demerits. One, it is difficult to determine the optimal number of collaborators needed to achieve the financial inclusion objective. Secondly, some collaborators may become inactive leaving the task for few active collaborators to do. Thirdly, having higher number of collaborators does not guarantee higher probability of achieving financial inclusion.

\subsection{Financial literacy theory of financial inclusion}

Financial literacy theory of financial inclusion states that financial inclusion should be achieved through education that increases the financial literacy of citizens. This theory argues that financial literacy will increase people's willingness to participate in the formal financial sector. The financial literacy theory has some merits. One, financial literacy can make people aware of financial products and services that are available to them. When they become aware of existing financial products and services that can improve their welfare, they will be willing to participate in the formal financial sector by owning a bank account. Secondly, through increased financial literacy, people can take advantage of other benefits in the formal financial sector such as investment and mortgage products. Thirdly, financial literacy can also help people become self-sufficient and can help them have some stability in their personal finance by helping them distinguish between needs and wants, helping them to create and manage a budget, teaching them to save so that they can pay bills when due, and to plan for retirement. Finally, governments that have limited public funds or limited tax revenue to fund financial inclusion activities may prefer to use financial literacy as a national financial inclusion strategy since it does not require much public funds to educate the population on the use of financial services.

The demerits of the financial literacy theory include the following. One, it addresses the 'willingness' not 'capacity' to participate in the formal financial sector. Financial literacy through education can improve the willingness of people to participate in the formal financial sector but it does not necessarily improve 'capacity' to participate in the formal financial sector where capacity is measured as having money which 
can be used to perform one or more transactions. This means that people who do not have money (that is, 'capacity') cannot actively participate in the financial sector even if they become financially-literate.

\section{Theories of financial inclusion funding}

The question: who should fund financial inclusion expenditure for the people - is an important question. Some think public money (tax-payers) should fund financial inclusion programs and activities (Marshall, 2004). Others feel that the capitalists in the private-sector should fund financial inclusion because they contributed to widen the income inequality gap between the poor and the rich (Mohiuddin, 2015). There are also ideas suggesting that financial inclusion should be jointly funded by the public and private sectors (Dashi et al, 2013; Cobb et al, 2016). Below are some theories of financial inclusion funding.

\subsection{Private money theory of financial inclusion}

Private money theory of financial inclusion states that financial inclusion activities should be funded using private money because private funders will require accountability from the users of their funds, and will ensure that private funds are utilized efficiently and ensure that financial products and services are delivered to the intended financially excluded members of the population.

The merits of private money theory include the following. One, there is shorter approval time to obtain private funding for financial inclusion projects compared to the long approvals for public funding. This is because private lenders can reach decisions more quickly since there are fewer processes through which the approval process must go. Secondly, private funders are often directly involved in financial inclusion activities either through equity ownership or other forms of participation. Thirdly, private funders can take ownership of the project, and can gain incomes and profits when they manage financial inclusion activities themselves. They can also exchange benefits with the local authorities. Four, it is easy to increase charges from users to meet the cost/budget of a contract with a private operator than by voting in local or national government to increase the cost or budget (Spackman, 2002). Five, private financiers can offer better project management skills, innovative facility and risk management in achieving financial inclusion objectives. Six, private funders can exert greater pressure on private contractors to finish all financial inclusion projects in good time while maintaining high quality.

Some demerits of private money theory include the following. One, the cost of raising private funds to fund financial inclusion projects may be high. Secondly, funding financial inclusion objectives using private money can increase private interests in financial inclusion outcomes to the detriment of the excluded population. Thirdly, there may be loss of government control over the financial inclusion infrastructure created by private investors due to partial or full private ownership.

\subsection{Public money theory of financial inclusion}

Public money theory of financial inclusion states that financial inclusion programs and activities should be funded using public money. This theory argues that financial inclusion programs and activities should be

funded from government budgets. There is evidence that public funding for financial inclusion is growing faster than private funding (see Dashie et al, 2013). Some merits of the public money theory include the 
following. One, the government can tax the rich to generate funds for financial inclusion projects for the benefit of all, and this would lead to the redistribution of wealth and reduce income inequality for the benefit of the poor and excluded population. Secondly, the cost of raising public funds to fund financial inclusion projects is low or negligible. Thirdly, funding financial inclusion objectives using public money can prevent unscrupulous individuals from hijacking the financial inclusion agenda for their own selfish benefit.

Some demerits of public money theory include the following. One, lack of proper planning is a major problem associated with public funding. Lack of planning can lead to overspending on financial inclusion projects, which can ultimately lead to inefficiency. Secondly, using public money to fund financial inclusion projects can lead to unnecessary delays in reaching the excluded population such as delays in disbursing funds, delays caused by lobbying and delays due to political events. Thirdly, governments with insufficient funds will be pressured to raise loans to finance financially inclusive projects, which can increase the debt burden of the government. Finally, improper delegation of authority may arise when the task of achieving financial inclusion is delegated to an incompetent authority or contractor. Usually, governments often make one of its competent agencies responsible for achieving financial inclusion objectives - governments often do this in order to save cost rather than creating a new agency. But such competent agency already has its existing statutory duties to perform and maybe overburdened with the task of achieving financial inclusion. These type of improper delegation of authority is common in many countries, and can lead to mistakes in achieving financial inclusion objectives.

\subsection{Intervention fund theory of financial inclusion}

The intervention fund theory of financial inclusion argues that financial inclusion activities and programs can be funded by special interventions from diverse related and unrelated funders rather than using taxpayers' money. It argues that many 'special funders' exist in the world such as philanthropists, nongovernmental organizations and foreign governments, and these special funders tend to support inclusive finance for the global population. In some economies, cross-border funding has the largest share of financial inclusion funding and much of these funding have been allocated to microfinance institutions (El-Zoghbi et al, 2011). Special funders can voluntarily and selectively choose the financial inclusion projects they wish to fund to completion and will provide the 'intervention fund' required to achieve the desired financial inclusion objectives. The goal of intervention funding for financial inclusion is to ensure that poor people and the financially-excluded population have access to formal financial services.

This theory has some merits. One, it by-passes the usual political bureaucracy associated with allocating public funds for public projects. Secondly, the special funders can mobilize financial and human resources, both locally and internationally, to assist them in achieving the desired financial inclusion objectives. Thirdly, special funders can create new institutions that are pro-development to help them achieve the desired financial inclusion objective, and these institutions will remain in the community to promote development even after the financial inclusion projects are completed.

The intervention fund theory has four demerits. Firstly, under this theory, special funders would need to develop a methodology to determine which segments of the population are excluded from the formal financial sector. Secondly, the method used by special funders to determine which population members 
are financially excluded may not accurately identify the intended target for financial inclusion. Thirdly, using intervention funds from foreign governments or foreign donors to fund development projects in a country can damage the reputation of a country as it signals that the government is unable to use its own funds to spur development for its own people.

\section{Future direction: applying the theories to data}

\subsection{Empirical data}

Data are records from past observations. Every data or observation from financial inclusion practice should be understood in terms of a prior, often implicit theory. This idea is consistent with Popper (1976) who argued that theory should precede observation. Data for financial inclusion can be obtained by using direct observations, interviews and surveys. Data obtained from financial inclusion practice and the analysis of such data should support or refute the above-discussed theories. Better theories of financial inclusion should replace poorer ones if they explain existing observations more effectively. Also, the empirical modelling of financial inclusion determinants should take into account the nature of the data and the magnitude of the explained and unexplained variation in a financial inclusion model.

\subsection{Case studies}

Scholars may use case studies on financial inclusion to develop interesting theories. Building a financial inclusion theory from case studies is a research strategy that involves using one or more cases to create theoretical constructs and propositions from case-based or empirical evidence (Eisenhardt, 1989). Case studies are often descriptions of particular instances of a phenomenon that are based on a variety of data sources (Yin, 1984). Cases can be historical accounts of financial inclusion success or failures in several countries. Each case study on financial inclusion can serve as a distinct experiment that stands on its own as an analytic unit while multiple case studies will serve as discrete experiments that serve as replications, contrasts, and extensions to the existing or emerging theories. Building theories from case studies on financial inclusion is likely to become a popular and more relevant research strategy for future studies on financial inclusion. Although case studies have some problems such as the small sample associated with case studies and the one-sided interviews that increases the informant bias, these issues can be mitigated by careful choice of sample and sample size, and by conducting fair interviews that limit the informants bias.

\section{Conclusion}

This paper presented new theories that can be used in financial inclusion research and policy debates. The purpose of this article has been to argue that financial inclusion needs to be studied from a theoretical perspective. Several theoretical perspectives have been provided. So far, many financial inclusion topics have yet to be sufficiently studied, and theories have been underutilized in the financial inclusion debate. The theories presented in this paper can serve as a guide for what needs to be done, but researchers who are not experts in financial inclusion will inevitably need more resources in addition to this one. 
This paper is a practical description and does not directly address how to test the relative effectiveness of the various financial inclusion theories or constructs for empirical modeling and critical discourse. Nevertheless, the paper does suggest ways in which using these theories can change how we think about financial inclusion beneficiaries, delivery agents and funding. Also, using these theories can remove from the literature extreme idealism. Using these theories will also help researchers make sure that the theoretical constructs they use are actually used all the way through the financial inclusion theory building process and will improve evidence-based summaries and thereby advance our understanding of financial inclusion.

A possible direction for future research is to develop a glossary of financial inclusion success stories across countries. Secondly, future studies can test these theories to identify which financial inclusion theories have the highest explanatory power in predicting the success of financial inclusion programmes and policies in different countries. Many additional theories of financial inclusion can be developed, and there is no limit to the number of new theories or ideas that can be developed or explored. Thirdly, there is need to test these theories using a rich sample such as a multi-country sample which is common among panel studies, or using time-series data for country-specific studies.

Finally, although this paper has argued the need of theory to understand financial inclusion, some advice for practitioners and policy makers are stated below. Digital finance and financial innovations should be used to achieve financial inclusion in a way that minimise tail risk to poor and vulnerable customers. Policies should be developed that encourage competition in the deivery of financial services. Governments should consider granting subsidy to providers of financial services so that they can offer basic financial services to the excluded population at a very low cost or free-of-charge. Governments should establish a communication channel that allows citizens to express their thoughts and concerns as to whether financial services are been offered to them fairly and at a cheap fee and without discrimination. 


\section{Reference}

Aggarwal, S., \& Klapper, L. (2013). Designing government policies to expand financial inclusion: Evidence from around the world. The Journal of Finance, 56(3), 1029-51.

Allen, F, Demirguc-Kunt, A, Klapper, L and Martinez Peria, M.S. (2016), The Foundations of Financial Inclusion: Understanding Ownership and Use of Formal Accounts, Journal of Financial Intermediation, 27, 1-30.

Arun, T., \& Kamath, R. (2015). Financial inclusion: Policies and practices. IIMB Management Review, 27(4), 267-287.

Bartholomew, L. K., \& Mullen, P. D. (2011). Five roles for using theory and evidence in the design and testing of behavior change interventions. Journal of Public Health Dentistry, 71, S20-S33.

Bhandari, B. S. (2018). Life Insurance-Social Security \& Financial Inclusion. Bimaquest, 18(2).

Cámara, N., \& Tuesta, D. (2015). Peru Model for Financial Inclusion: E-Money Potential Adopters. BBVA Research, Financial.

Chibba, M. (2009). Financial inclusion, poverty reduction and the millennium development goals. The European Journal of Development Research, 21(2), 213-230.

Cobb, J. A., Wry, T., \& Zhao, E. Y. (2016). Funding financial inclusion: Institutional logics and the contextual contingency of funding for microfinance organizations. Academy of Management Journal, 59(6), 21032131.

Cull, R., Cull, R. J., Demirgüç-Kunt, A., \& Morduch, J. (Eds.). (2013). Banking the world: empirical foundations of financial inclusion. MIT Press.

Dashi, E., Lahaye, E., \& Rizvanolli, R. (2013). Trends in International Funding for Financial Inclusion.

Demirguc-Kunt, A., Klapper, L., \& Singer, D. (2017). Financial inclusion and inclusive growth: A review of recent empirical evidence. The World Bank.

Demirgüç-Kunt, A., \& Klapper, L. (2013a). Measuring financial inclusion: Explaining variation in use of financial services across and within countries. Brookings Papers on Economic Activity, 2013(1), 279-340.

Demirguc-Kunt, A., Klapper, L., \& Singer, D. (2013b). Financial inclusion and legal discrimination against women: evidence from developing countries. The World Bank.

Dev, S. M. (2006). Financial inclusion: Issues and challenges. Economic and political weekly, 4310-4313.

Eisenhardt, K. M. 1989b. Building theories from case study research. Academy of Management Review, 14: $532-550$.

El-Zoghbi, M., Gähwiler, B., \& Lauer, K. (2011). Cross-border Funding of Microfinance. CGAP Focus Note 70. Washington DC: CGAP. 
Gabor, D., \& Brooks, S. (2017). The digital revolution in financial inclusion: international development in the fintech era. New Political Economy, 22(4), 423-436.

Ghosh, S., \& Vinod, D. (2017). What constrains financial inclusion for women? Evidence from Indian micro data. World Development, 92, 60-81.

Hove, L. V., \& Dubus, A. (2019). M-PESA and Financial Inclusion in Kenya: Of Paying Comes Saving? Sustainability, 11(3), 568.

Jensen, M. C., \& Meckling, W. H. (1976). Theory of the firm: Managerial behavior, agency costs and ownership structure. Journal of financial economics, 3(4), 305-360.

Lichtenstein, J. (2018). Financial Inclusion in Rwanda: Examining policy implementation and impact on community and household lives (Doctoral dissertation, University of Cambridge).

Marshall, J. N. (2004). Financial institutions in disadvantaged areas: a comparative analysis of policies encouraging financial inclusion in Britain and the United States. Environment and Planning A, 36(2), 241261.

Mehrotra, A. N., \& Yetman, J. (2015). Financial inclusion-issues for central banks. BIS Quarterly Review March.

Mohiuddin, S. (2015). Private Sector Leadership in Financial Inclusion. Corporate Citizenship Center, U.S. Chamber of Commerce Foundation. Available at: https://www.uschamberfoundation.org/sites/default/files/Private\%20Sector\%20Leadership\%20in\%20Fi nancial\%20Inclusion Web.pdf

Morgan, P., \& Pontines, V. (2014). Financial stability and financial inclusion.

Ndung'u, N. (2018). The M-Pesa technological revolution for financial services in Kenya: A platform for financial inclusion. In Handbook of Blockchain, Digital Finance, and Inclusion, Volume 1 (pp. 37-56). Academic Press.

Nimbrayan, P. K., Tanwar, N., \& Tripathi, R. K. (2018). Pradhan mantri jan dhan yojana (PMJDY): The biggest financial inclusion initiative in the world. Economic Affairs, 63(2), 583-590.

Otioma, C., Madureira, A. M., \& Martinez, J. (2019). Spatial analysis of urban digital divide in Kigali, Rwanda. GeoJournal, 84(3), 719-741.

Ozili, P. K. (2018). Impact of digital finance on financial inclusion and stability. Borsa Istanbul Review, 18(4), 329-340.

Pearce, D. (2011). Financial inclusion in the Middle East and North Africa: Analysis and roadmap recommendations. The World Bank.

Popper, K. R. (1976). The myth of the framework. In E. Freeman (Ed.), The abdication of philosophyPhilosophy and the public good: Essays in honor of Paul Arthur Schilpp (pp. 23-48). LaSalle, IL: Open Court. Prabhakar, R. (2019). Financial inclusion: A tale of two literatures. Social Policy and Society, 18(1), 37-50. 
Sahay, R., Čihák, M., N'Diaye, P. M. B. P., Barajas, A., Mitra, S., Kyobe, A., ... \& Yousefi, S. R. (2015). Financial inclusion: Can it meet multiple macroeconomic goals? (No. 15/17). Washington: International Monetary Fund.

Spackman, M (2002). Public-Private partnerships: lessons from the british approach. Economic Systems, 26(3), pp. 283-301.

Staschen, S., \& Nelson, C. (2013). The role of government and industry in financial inclusion.

Staschen, S. and Nelson, C. (2013) 'The Role of Government and Industry in Financial Inclusion', in J. Ledgerwood (ed.), The New Microfinance Handbook: A Financial Market System Perspective, Washington DC: World Bank.

Swamy, V. (2014). Financial inclusion, gender dimension, and economic impact on poor households. World development, 56, 1-15.

Sarma, M., \& Pais, J. (2011). Financial inclusion and development. Journal of international development, 23(5), 613-628.

World Bank (2018). Financial Inclusion. Avaialble at: https://www.worldbank.org/en/topic/financialinclusion/overview accessed on 27/07/2019

Kim, D. W., Yu, J. S., \& Hassan, M. K. (2018). Financial inclusion and economic growth in OIC countries. Research in International Business and Finance, 43, 1-14. 


\section{Appendix}

\begin{tabular}{|c|c|c|c|c|}
\hline $\mathrm{S} / \mathrm{N}$ & Theory & Category & Merit/Advantage & Demerit/Advantages \\
\hline 1. & $\begin{array}{l}\text { Public good } \\
\text { theory }\end{array}$ & $\begin{array}{l}\text { financial inclusion } \\
\text { beneficiary }\end{array}$ & $\begin{array}{l}\text { (i) everyone will benefit from } \\
\text { financial inclusion and nobody will } \\
\text { be left out; (ii) achieved through } \\
\text { public funding; (iii) the State takes } \\
\text { responsbility for financial } \\
\text { inclusion }\end{array}$ & $\begin{array}{l}\text { (i) it does not address the real cause } \\
\text { of financial exclusion; (ii) it diverts } \\
\text { public funding away from other } \\
\text { important national projects; (iii) } \\
\text { financial inclusion may become } \\
\text { unsustainable when treated as a } \\
\text { public good; (iv) may not be useful } \\
\text { in explaining financial inclusion in } \\
\text { developing and underdeveloped } \\
\text { countries }\end{array}$ \\
\hline 2. & $\begin{array}{l}\text { Dissatisfaction } \\
\text { theory }\end{array}$ & $\begin{array}{l}\text { financial inclusion } \\
\text { beneficiary }\end{array}$ & $\begin{array}{l}\text { (i) it deals with the voluntary } \\
\text { financial exclusion problem; (ii) it } \\
\text { is easy to identify the financially- } \\
\text { excluded members of the } \\
\text { population; (iii) achieving financial } \\
\text { inclusion does not require the use } \\
\text { of public funds. }\end{array}$ & $\begin{array}{l}\text { (i) the theory does not prioritize } \\
\text { financial inclusion for everybody in } \\
\text { the population; (ii) it ignores poor } \\
\text { people in remote areas where } \\
\text { formal financial institutions do not } \\
\text { exist; (iii) financial exclusion may } \\
\text { not be caused by customers' } \\
\text { dissatisfaction with the formal } \\
\text { financial sector. }\end{array}$ \\
\hline 3. & $\begin{array}{l}\text { Vulnerable } \\
\text { group theory }\end{array}$ & $\begin{array}{l}\text { financial inclusion } \\
\text { beneficiary }\end{array}$ & $\begin{array}{l}\text { (i) reduces the financial exclusion } \\
\text { problem by targeting vulnerable } \\
\text { groups; (ii) it is easy to identify the } \\
\text { financially-excluded members of } \\
\text { the population; (iii) it is cost- } \\
\text { effective to target only the } \\
\text { vulnerable members of the } \\
\text { population }\end{array}$ & $\begin{array}{l}\text { (i) does not prioritize financial } \\
\text { inclusion for everybody in the } \\
\text { population; (ii) it ignores non- } \\
\text { vulnerable people outside the } \\
\text { formal financial sector; } \\
\text { (iii) it assumes that women are a } \\
\text { vulnerable group, which suggest } \\
\text { that men are not a vulnerable } \\
\text { group. }\end{array}$ \\
\hline 4. & $\begin{array}{l}\text { Systems theory } \\
\text { of financial } \\
\text { inclusion }\end{array}$ & $\begin{array}{l}\text { financial inclusion } \\
\text { beneficiary }\end{array}$ & $\begin{array}{l}\text { (i) it recognizes the role of existing } \\
\text { sub-systems (economic, financial } \\
\text { and social systems or structures) } \\
\text { in a country in promoting financial } \\
\text { inclusion; (ii) it views financial } \\
\text { inclusion from a macro } \\
\text { perspective; (iii) it considers how } \\
\text { financial inclusion outcomes are } \\
\text { affected by the interrelationship } \\
\text { among existing sub-systems }\end{array}$ & $\begin{array}{l}\text { (i) it does not recognize the } \\
\text { influence of factors outside the } \\
\text { system that could affect financial } \\
\text { inclusion outcomes; (ii) it assumes } \\
\text { that there is a direct relationship } \\
\text { between financial inclusion } \\
\text { outcomes and the systems it relies } \\
\text { on. }\end{array}$ \\
\hline
\end{tabular}




\begin{tabular}{|c|c|c|c|c|}
\hline 5. & $\begin{array}{l}\text { Community } \\
\text { echelon theory }\end{array}$ & $\begin{array}{l}\text { financial inclusion } \\
\text { delivery }\end{array}$ & $\begin{array}{l}\text { (i) communal leaders can } \\
\text { influence community members } \\
\text { into making changes that improve } \\
\text { their welfare. }\end{array}$ & $\begin{array}{l}\text { (i) the influence of communal } \\
\text { leaders can rebound if communal } \\
\text { leaders are self-serving and corrupt; } \\
\text { (ii) communal leaders can make } \\
\text { abrupt decisions that are not in the } \\
\text { best interest of the people; (iii) } \\
\text { communal leaders can be pressured } \\
\text { to make decisions that are not in } \\
\text { the best interest of the community } \\
\text { members; (iv) serious agency } \\
\text { problems may arise in form of } \\
\text { nepotism, fraud and corruption. }\end{array}$ \\
\hline 6. & $\begin{array}{l}\text { Public service } \\
\text { theory }\end{array}$ & $\begin{array}{l}\text { financial inclusion } \\
\text { delivery }\end{array}$ & $\begin{array}{l}\text { (i) financial inclusion can be } \\
\text { achieved when the government is } \\
\text { responsible for financial inclusion; } \\
\text { (ii) the government can use the } \\
\text { existing economic, social and } \\
\text { political systems to achieve its } \\
\text { financial inclusion objectives; (iii) } \\
\text { there is increased public } \\
\text { confidence when public } \\
\text { institutions assumes full } \\
\text { responsibility for financial } \\
\text { inclusion }\end{array}$ & $\begin{array}{l}\text { (i) it does not consider private- } \\
\text { sector participation in promoting } \\
\text { financial inclusion; (ii) tax revenue } \\
\text { may be insufficient to fund large } \\
\text { financial inclusion programs. }\end{array}$ \\
\hline 7. & $\begin{array}{l}\text { Special agent } \\
\text { theory }\end{array}$ & $\begin{array}{l}\text { financial inclusion } \\
\text { delivery }\end{array}$ & $\begin{array}{l}\text { (i) it requires the services of } \\
\text { specialized agents to promote } \\
\text { financial inclusion in the country; } \\
\text { (ii) it allows the government to } \\
\text { focus on other important and } \\
\text { pressing national issues; (iii) there } \\
\text { is high degree of confidence in the } \\
\text { ability of special agents; (iv) there } \\
\text { is no ambiguity about the financial } \\
\text { inclusion targets to be achieved; } \\
\text { (v) the special agent relationship is } \\
\text { not affected by the fundamental } \\
\text { principal-agent problems in } \\
\text { agency theory. }\end{array}$ & $\begin{array}{l}\text { (i) the government may choose its } \\
\text { own agency as the special agent, } \\
\text { making the government both the } \\
\text { principal and the agent; (ii) the } \\
\text { private special agent can abandon } \\
\text { the financial inclusion project if } \\
\text { contractual terms are breached. }\end{array}$ \\
\hline 8. & $\begin{array}{l}\text { Collaborative } \\
\text { theory }\end{array}$ & $\begin{array}{l}\text { financial inclusion } \\
\text { delivery }\end{array}$ & $\begin{array}{l}\text { (i) it encourages a multi- } \\
\text { stakeholder approach to achieve } \\
\text { financial inclusion; (ii) the }\end{array}$ & $\begin{array}{l}\text { (i) it is difficult to determine the } \\
\text { optimal number of collaborators } \\
\text { needed to achieve financial }\end{array}$ \\
\hline
\end{tabular}




\begin{tabular}{|c|c|c|c|c|}
\hline & & & $\begin{array}{l}\text { collaborating stakeholders have a } \\
\text { sense of satisfaction for being a } \\
\text { significant contributor to a public } \\
\text { project. }\end{array}$ & $\begin{array}{l}\text { inclusion objectives; (ii) some } \\
\text { collaborators may become inactive } \\
\text { leaving the task for few active } \\
\text { collaborators to do; (iii) having } \\
\text { higher number of collaborators } \\
\text { does not guarantee higher } \\
\text { probability of achieving financial } \\
\text { inclusion. }\end{array}$ \\
\hline 9. & $\begin{array}{l}\text { Financial } \\
\text { literacy }\end{array}$ & $\begin{array}{l}\text { financial inclusion } \\
\text { delivery }\end{array}$ & $\begin{array}{l}\text { (i) Financial literacy increases } \\
\text { awareness of available basic } \\
\text { financial services; (ii) financial } \\
\text { literacy can help people become } \\
\text { self-sufficient and can help them } \\
\text { have some stability in their } \\
\text { personal finance; } r \text { (iii) } \\
\text { governments that have limited } \\
\text { public funds may prefer to use } \\
\text { financial literacy as a national } \\
\text { financial inclusion strategy since it } \\
\text { does not require much public fund }\end{array}$ & $\begin{array}{l}\text { (i) the financial literacy theory } \\
\text { addresses the 'willingness' not } \\
\text { 'capacity' to participate in the } \\
\text { formal financial sector. }\end{array}$ \\
\hline 10. & $\begin{array}{l}\text { Private money } \\
\text { theory }\end{array}$ & $\begin{array}{l}\text { financial inclusion } \\
\text { funding }\end{array}$ & $\begin{array}{l}\text { (i) there is shorter approval time } \\
\text { to obtain private funding for } \\
\text { financial inclusion projects; (ii) } \\
\text { private funders are directly } \\
\text { involved through equity } \\
\text { ownership or other forms of } \\
\text { participation; (iii) private funders } \\
\text { can take ownership of the project; } \\
\text { (iv) private financiers can offer } \\
\text { better project management skills, } \\
\text { innovative facility and risk } \\
\text { management in achieving } \\
\text { financial inclusion objectives; (iv) } \\
\text { private funders can exert greater } \\
\text { pressure on private contractors to } \\
\text { finish all financial inclusion } \\
\text { projects in good time while } \\
\text { maintaining high quality. }\end{array}$ & $\begin{array}{l}\text { (i) the cost of raising private funds } \\
\text { to fund financial inclusion projects } \\
\text { may be high; (ii) funding financial } \\
\text { inclusion objectives using private } \\
\text { money can increase private } \\
\text { interests in financial inclusion } \\
\text { outcomes; (iii) there may be loss of } \\
\text { government control over the } \\
\text { financial inclusion infrastructure } \\
\text { created by private investors. }\end{array}$ \\
\hline 11. & $\begin{array}{l}\text { Public money } \\
\text { theory }\end{array}$ & $\begin{array}{l}\text { financial inclusion } \\
\text { funding }\end{array}$ & $\begin{array}{l}\text { (i) the government can tax the rich } \\
\text { to generate funds for financial }\end{array}$ & $\begin{array}{l}\text { (i) lack of proper planning is a major } \\
\text { problem associated with public } \\
\text { funding; (ii) using public money to }\end{array}$ \\
\hline
\end{tabular}




\begin{tabular}{|c|c|c|c|c|}
\hline & & & $\begin{array}{l}\text { inclusion projects for the benefit } \\
\text { of all. } \\
\text { (ii) the cost of raising public funds } \\
\text { to fund financial inclusion projects } \\
\text { is low or negligible; (iii) funding } \\
\text { financial inclusion objectives using } \\
\text { public money can prevent } \\
\text { individuals from hijacking the } \\
\text { financial inclusion agenda for self- } \\
\text { benefit. }\end{array}$ & $\begin{array}{l}\text { fund financial inclusion projects can } \\
\text { lead to unnecessary delays in } \\
\text { reaching the excluded population; } \\
\text { (iii) governments with insufficient } \\
\text { funds may be pressured to obtain } \\
\text { loans which will increase the } \\
\text { national debt level; (iv) improper } \\
\text { delegation of authority may arise } \\
\text { when the task of achieving financial } \\
\text { inclusion is delegated to an } \\
\text { incompetent authority or } \\
\text { contractor. }\end{array}$ \\
\hline 12. & $\begin{array}{l}\text { Intervention } \\
\text { fund theory }\end{array}$ & $\begin{array}{l}\text { financial inclusion } \\
\text { funding }\end{array}$ & $\begin{array}{l}\text { (i) it by-passes the usual political } \\
\text { bureaucracy associated with } \\
\text { allocating public funds for public } \\
\text { projects; (ii) the special funders } \\
\text { can mobilize financial and human } \\
\text { resources, both locally and } \\
\text { internationally, to achieve the } \\
\text { desired financial inclusion } \\
\text { objectives; (iii) special funders can } \\
\text { create new institutions that are } \\
\text { pro-development to help them } \\
\text { achieve the desired financial } \\
\text { inclusion objective }\end{array}$ & $\begin{array}{l}\text { (i) special funders would need to } \\
\text { develop a methodology to } \\
\text { determine which segments of the } \\
\text { population are excluded from the } \\
\text { formal financial sector; (ii) special } \\
\text { funders may use an unfair } \\
\text { methodology or criteria to } \\
\text { determine which population } \\
\text { members are financially excluded; } \\
\text { (iii) using intervention funds from } \\
\text { foreign governments or foreign } \\
\text { donors to fund development } \\
\text { projects in a country can damage } \\
\text { the reputation of the country. }\end{array}$ \\
\hline
\end{tabular}

